FACTA UNIVERSITATIS

Series: Philosophy, Sociology, Psychology and History Vol. 17, Nº 1, 2018, pp. 71 - 88

https://doi.org/10.22190/FUPSPH1801071V

Review Paper

\title{
TECHNOAESTHETICS: SOME REMARKS ON THE COVERGENCE OF AESTHETICS AND TECHNOLOGY
}

\author{
UDC 111.852
}

\section{Maroje Višić}

Dubrovnik, Croatia

\begin{abstract}
Author analyses the question and application of technology. Author draws on works of Heidegger, Marcuse and Jonas. The emphasis is put on Marcuse since he developed best theory of liberation through technology and offered a detailed vision of aesthetic ethos. Author first discusses Heidegger's understanding of technology which largely influenced Marcuse. Then, author discusses Jonas' proposition for a new ethics for technological civilization. Finally, drawing on Heidegger, Marcuse, Jonas and Simondon, author proposes term "technoaesthetics" as a notion that describes and captures a qualitatively different idea of a usage and application of technology.
\end{abstract}

Key words: art, technology, technics, liberation, Heidegger, Marcuse, Jonas, technological rationality, technoaesthetics.

\section{INTRODUCTION}

The aim of this paper is to thoroughly examine the question and application of technology and perhaps offer a new theoretical perspective on the usage of technology expressed through the notion of "technoaesthetics". In this attempt I will draw on Heidegger's, (especially) Marcuse's and Jonas' works. These philosophers laid milestones and profoundly changed the understanding of technology - namely the very essence of technology. Heidegger refuted the common understanding of technology as something instrumental and argued that technology is a mode of enframing and revealing. Marcuse's works characterizes lifelong searching for liberation and emancipation of the individuals. The question of technology occupies a significant place in Marcuse's critical theory. It is precisely in technology which transformed not only the character of labor but societies in general that Marcuse saw the strongest revolutionary potential for the "qualitative change". Thus, it could be said that Marcuse perceived technology as a new ontology. At last Jonas comes after the technology that failed to deliver the promise of liberation

Received April 23, 2017 / Accepted May 27, 2018

Corresponding author: Maroje Višić

Dubrovnik, Croatia

E-mail: maroje_asi@yahoo.com 
which Marcuse constantly emphasized. The world changing experience of the atomic bomb corroborated Heidegger's warning that the very essence of technology holds the greatest peril for humanity. Profoundly affected with this enormous life-threatening potential of technology, Jonas reformulates Kant's categorical imperative stating that life (as an omnipresent) idea must exist and that no one has any claims to endanger life on Earth. Thus, by introducing the notion of "technoaesthetics" I will attempt to capture and describe the new mode of usage of technology that as it seems is fundamental to Heidegger, Marcuse and Jonas.

\section{THE ESSENCE OF TECHNOLOGY}

To completely comprehend Marcuse's argument, it is unavoidable to mention Marcuse's philosophical debt to Martin Heidegger. Heidegger's influence on Marcuse's thought is unquestioned and it is also present in Marcuse's dealings with technology. ${ }^{1}$

Heidegger differentiates between technics in Greek understanding and modern technic. In the former technics is part of the poiesis. It relates to a mode of production as well as art - technics which the artist uses in creating art. In the modern sense, Heidegger (1977) argues, technics is not a part of poiesis. Modern technics is used for bringing-forth which means revealing something that is hidden. To put it in Heidegger's words: "What has the essence of technology to do with revealing? The answer: everything. For every bringingforth is grounded in revealing (...) Instrumentality is considered to be fundamental characteristic of technology (...) Technology is therefore no more means. Technology is a way of revealing" (Heidegger 1977, 5). What Heidegger tries to demonstrate is that revealing (unconcealment) is not part of poiesis and that this way of revealing profoundly affects human perception of the world and nature. So according to Heidegger the unconcealing in modern technic has a form, an essence of setting-in-order in the sense of

\footnotetext{
${ }^{1}$ Heidegger's influence on Marcuse should be noted here in order to dismiss Schoolman's (1984) misinterpretation of Marcuse. Schoolman (1984) argues that Marcuse's understanding of technology is largely influenced by Weber's notion of rationality while Heidegger's influence is menial. Schoolman's (1984) argument is that Marcuse closely follows Weber according to whom domination is immanent to technological rationality. In the essay Industrialization and Capitalism in the Work of Max Weber Marcuse is critical of Weber and he clearly demonstrates, contrary to Schoolman's (1984) claim, that: "But it is precisely here, at this most decisive point, where Weber's analysis becomes self-criticism, that one can see how much this analysis has fallen prey to the identification of technical reason with bourgeois capitalist reason. This identification prevents him from seeing that not 'pure', formal, technical reason but the reason of domination erects the 'shell of bondage', and that the consummation of technical reason can well become the instrument for the liberation of man" (Marcuse 1937, 167). As I tried to show it is precisely Heidegger's notion of "standing-reserve" that is central to Marcuse's understanding of technology. Like Heidegger, Marcuse also sought liberating possibilities that technology could offer and this is so much unlike Weber's understanding: "On the basis of its own achievements, that is, of productive and calculable mechanization, this separation contains the potentiality of a qualitatively different rationality, in which separation from the means of production becomes the separation of man from the socially necessary labor that de-purposiveness would be no longer 'antinomical'; nor would administer automated production, formal and substantive purposiveness would be no longer 'antinomical'; nor would formal reason prevail indifferently among and over men. For, as 'congealed spirit', the machine is not neutral; technical reason is the social reason ruling a given society and can be changed in its very structure. As technical reason, it can become the technique of liberation. For Max Weber this possibility was utopian. Today it looks as if he was right. But if contemporary industrial society defeats and triumphs over its own potentialities, then this triumph is no longer that of Max Weber's bourgeois reason" (Marcuse 1937, 169).

Regarding Heidegger's "menial" influence on Marcuse, it suffices to cite the acknowledgments from Marcuse's habilitation: "Any contribution this work may make on the development and clarification of problems is indebted to the philosophical work of Martin Heidegger" (Marcuse 1987[1932], 5).
} 
challenging forth. ${ }^{2}$ According to Heidegger (1977) modern technic characterizes scientific relation toward nature which is evident in the accumulation of energy resources ever ready to be distributed. This is what Heidegger (1977) calls "standing-reserve" (Bestand) and argues that this should be understood in terms of enframing and ordering. It is in the "standing-reserve" and not in the instrumental use of technic that Heidegger saw the greatest peril for men. That peril lies in the possibility that "standing-reserve" becomes the single mode of revealing. If this is to happen, then man would be absorbed by technics by becoming himself part of "standing-reserve". To put it in Heidegger's words: "The essence of technology lies in Enframing. Its holding sway belongs within destining. Since destining at any given time starts man on a way of revealing, man, thus under way, is continually approaching the brink of the possibility of pursuing and pushing forward nothing but what is revealed in ordering, and of deriving all his standards on this basis. Through this the other possibility is blocked, that man might be admitted more and sooner and ever more primary to the essence of that which is unconcealed and to its unconcealment, in order that he might experience as his essence his needed belonging to revealing. Placed between these possibilities, man is endangered from out of destining. The destining of revealing is as such, in every one of its modes, and therefore necessarily, danger (...) yet when destining reigns in the mode of Enframing, it is the supreme danger. This danger attests itself to us in two ways. As soon as what is unconcealed no longer concerns man even as object, but does so, rather, exclusively as standing-reserve, and man in the midst of objectlessness is nothing but the orderer of the standing-reserve, then he comes to the very brink of a precipitous fall; that is, he comes to the point where he himself will have to be taken as standing-reserve" (Heidegger 1977, 13-14).

\footnotetext{
${ }^{2}$ To demonstrate how technology affects human understanding of world and nature Heidegger offers an example of the Rhine river: "The hydroelectric plant is set into the current of the Rhine. It sets the Rhine to supplying its hydraulic pressure, which then sets the turbines turning. This turning sets those machines in motion whose thrust sets going the electric current for which the long-distance power station and its network of cables are set up to dispatch electricity. In the context of the interlocking processes pertaining to the orderly disposition of electrical energy, even the Rhine itself appears as something at our command. The hydroelectric plant is not built into the Rhine River as was the old wooden bridge that joined bank with bank for hundreds of years. Rather the river is dammed up into the power plant. What the river is now, namely, a water power supplier, derives from out of the essence of the power station. In order that we may even remotely consider the monstrousness that reigns here, let us ponder for a moment the contrast that speaks out of the two titles, "The Rhine" as dammed up into the power works, and 'The Rhine' as uttered out of the art work, in Hölderlin's hymn by that name. But, it will be replied, the Rhine is still a river in the landscape, is it not? Perhaps. But how? In no other way than as an object on call for inspection by a tour group ordered there by the vacation industry. The revealing that rules throughout modern technology has the character of a setting-upon, in the sense of a challenging-forth" (Heidegger 1977, 7).

Compared with Marcuse's example it could be noted that he almost paraphrases Heidegger: "Let us take a simple example. A man who travels by automobile to a distant place chooses his route from the highway maps. Towns, lakes and mountains appear as obstacles to be bypassed. The countryside is shaped and organized by the highway: what one finds en route is a byproduct or annex of the highway. Numerous signs and posters tell the traveler what to do and think; they even request his attention to the beauties of nature or the hallmarks of history. Others have done the thinking for him, and perhaps for the better. Convenient parking spaces have been constructed where the broadest and most surprising view is open. Giant advertisements tell him when to stop and find the pause that refreshes. And all of this is indeed for his benefit, safety and comfort; he receives what he wants. Business, technics, human needs and nature are welded together into one rational and expedient mechanism. He will fare best who follows its directions, subordinating his spontaneity to the anonymous wisdom which ordered everything for him" (Marcuse 1941, 46).
} 
Even though Heidegger's treatment of modern technology is somehow pessimistic for the men's destiny he still offers a glimpse of hope. As a dialectical thinker, Heidegger believed that everything in itself holds a negation which means that something is not what it is or that by negating itself could become something else. The same principle of negation applies to the essence "standing-reserve" of modern technology and offers a hope in deliverance. Heidegger demonstrates this saving possibility: "But what help is it to us to look into the constellation of truth? We look into the danger and see the growth of the saving power. Through this we are not yet saved. But we are thereupon summoned to hope in the growing light of the saving power. How can this happen? Here and now and in little things, that we may foster the saving power in its increase. This includes holding always before our eyes the extreme danger. The coming to presence of technology threatens revealing, threatens it with the possibility that all revealing will be consumed in ordering and that everything will present itself only in the unconcealedness of standing-reserve. Human activity can never directly counter this danger. Human achievement alone can never banish it. But human reflection can ponder the fact that all saving power must be of the higher essence than what is endangered, though at the same time kindred to it" (Heidegger 1977, 18). Heidegger emphasized the power of reason in this liberation from "standingreserve". The reason alone needs to be guided and this guidance is found in art. The art by her poetic revealing counters the technological mode of revealing. So reasoning on technology must happen from the realm of aesthetics. On this question Heidegger concludes: "Because the essence of technology is nothing technological, essential reflection upon technology and decisive confrontation with it must happen in a realm that is, on the one hand, akin to the essence of technology and, on the other, fundamentally different from it. Such a realm is art. But certainly only if reflection on art, for its part, does not shut its eyes to the constellation of truth after which we are questioning. Thus questioning, we bear witness to the crisis that in our sheer preoccupation with technology we do not yet experience the coming to presence of technology, that in our sheer aesthetic-mindedness we no longer guard and preserve the coming to presence of art. Yet the more questioningly we ponder the essence of technology, the more mysterious the essence of art becomes" (Heidegger 1977, 19).

\section{TECHNOLOGICAL RATIONALITY}

Although Marcuse explicitly discussed technology in his perhaps best-known works Eros and Civilization and One Dimensional Man I will consider the question of technology by analyzing the complete works of Herbert Marcuse. This analysis is necessary in order to avoid misunderstandings about the alleged inconsistence in Marcuse's thoughts on technology. For example, reflecting on the 50 years after publishing One Dimensional Man Whitfield argues: "Nor are Eros and Civilization and One-Dimensional Man entirely consistent. For example, Eros and Civilization envisions technology as a catalyst of emancipation, freeing humanity from drudgery and permitting a polymorphous sexuality to pervade utopia. The latter book repudiates technocratic bureaucracy, however, and condemns the exploitation of nature that scientific progress is supposed to achieve" (Whitfield 2014, 106). Whitfield has misconceptions about Marcuse's understanding of 
technology due to his unfamiliarity with Marcuse's complete opus and especially Marcuse's early works which are actually the keys to understanding his later writings. ${ }^{3}$ Marcuse was consistent in thinking that technology could bring liberation. The only difference was that at first he thought that liberation is inherent in technological development and later he argued that it is a political decision to use technology in a liberating way. This article will attempt to clarify the fallacy regarding the role of technology in Marcuse's works.

Before examining in detail the political role of technology, it is important to note that the signs of the technology as a new ontology are already present in the essays from the 1920 s to 1930 s which can be located to Marcuse's "heideggerian-marxism" or "phenomenological marxism" period. In On the Concrete Philosophy Marcuse writes: "An example: in the intoxication of power that has accompanied advancements in technology and rationalization in contemporary society, it has been overlooked that the personal power of humans over nature and 'things' has not increased, but decreased! Just as humans as 'economic subjects and objects' find themselves in thrall to a commodity economy that has become a self-sufficient 'entity', rather than in a situation where their industry is an appropriate mode of their existing, so it is that their tools-machines, means of transportation, electricity, light, power-have become for them so large and burdensome that, seen from the perspective of the individual, those people who use these tools must increasingly adapt their existences to suit them, must enter into their service. Indeed, it becomes clear that ever more lives are being consumed in order to keep them 'functioning'!' (Marcuse 1929, 43-44).

The essay Some Implications of Modern Technology represents a turning point in Marcuse's search for the subject of a revolution. It is evident that Marcuse perceived the proletariat's impotence to bring about revolution due to its integration into society which was largely based upon rapid technological advancement which rendered physically exhausting labor obsolete. This fact offered Marcuse an argument that technology in itself holds catalytic potential for advancement of freedom and even more a reduction of time spent at work.

Marcuse's thoughts on technology are profoundly influenced by Heidegger's above mentioned arguments. Especially Marcuse's term "technological rationality" is deeply rooted in Heidegger's understanding of "standing-reserve". Where Heidegger thought of potential danger for men to be absorbed by technology Marcuse thought it had already happened and termed it "technological rationality". Following Heidegger, Marcuse emphasized the emancipatory potential in the essence of technology and in his later works Marcuse developed Heidegger's argument on art and technology further by envisioning the

\footnotetext{
${ }^{3}$ Habermas (1968) argues that it is impossible to understand Marcuse, especially Eros and the Civilization, without studying his early works. Marcuse's critics also emphasized the importance and continuity of his early works. Farr argues: "Marcuse's work on Freud must be taken as only a moment within a larger more complex project" (Farr 2009, 63). Schoolman is also aware of this fact: "Criticism is focused largely upon Marcuse's thought as it took shape after 1933. But before the nightmarish shock of that year produced a dramatic turn in Marcuse's thinking, his early work had constituted a significant project that ought to be pursued by contemporary social theory..." (Schoolman, 1984: xiii). Perhaps the best statement on this has been offered by the critic MacIntyre: "The importance of this early papers does not lie only in the fact that they constitute a first statement of the thesis which informs the whole of his later work. For on certain points they are more explicit than anything in the later work" (MacIntyre 1970, 16).
} 
cooperation of technology and art in creating a new society. A detailed examination of Marcuse's thoughts on technology follows.

Like Heidegger, Marcuse also sees dualistic potential of technology: a danger and a liberation force: "Technics by itself can promote authoritarianism as well as liberty, scarcity as well as abundance, the extension as well as abolition of toil" (Marcuse 1941, 41). But while Heidegger thought that deliverance can be approached by thinking as a distinctive human category, Marcuse observed that the technological advancement created a new form of rationality - "technological rationality" which subdued humankind to technological apparatus. Marcuse describes this argument: "Technology, as a mode of production, as the totality of instruments, devices and contrivances which characterize the machine age is thus at the same time a mode of organizing and perpetuating (or changing) social relationships, a manifestation of prevalent thought and behavior patterns, an instrument for control and domination (...) In the course of the technological process a new rationality and new standards of individuality have spread over society, different from and even opposed to those which initiated the march of technology" (Marcuse 1941, 41-42). What Marcuse observed was that the development of technology directly affected the creation of new rationality and individuality. But Marcuse immediately emphasized that this is not due to the instrumentalist usage of technology (same as Heidegger (1977) argued) but that it is the sole factor in its essence and development. In order to demonstrate this argument Marcuse (1941) contrasts the idea of individuality in the $16^{\text {th }}$ and $17^{\text {th }}$ century with the new technological individuality. Marcuse argues that in the former the interest of the individual did not necessarily overlap with the interests of society and thus the individual was free in criticizing dominant norms of society and in seeking and realizing true norms. The realization of these norms was possible in liberal society as this mode of social organization offered the possibilities for development of individual rationality. Marcuse (1941) argues that the individuality demonstrated itself in the sphere of free competition, goods and services which became an integral part of a society's needs. In Marcuse's opinion, the development of mechanization and rationality based upon competitive effectiveness and in favoring companies with highly mechanized industrial equipment instead of individual entrepreneur abolished this $16^{\text {th }}$ and $17^{\text {th }}$ century idea of individualism. For Marcuse (1941) this kind of efficiency means profit, and profit means profitable employment of the apparatus to the extent that it dictates quantitative production and distribution of goods and through this power technology affects entire rationality thus creating a new kind of rationality - technological rationality. Marcuse describes technological rationality as: "Under the impact of this apparatus, individualistic rationality has been transformed into technological rationality. It is by no means confined to the subjects and objects of large scale enterprises but characterizes the pervasive mode of thought and even the manifold forms of protest and rebellion. This rationality establishes standards of judgment and fosters attitudes which make men ready to accept and even to introcept the dictates of the apparatus" (Marcuse 1941, 44).

Marcuse (1941) argues that individuality under the technological rationality is transformed into standardized efficiency in which the individual is considered efficient if his freedom and actions are in accordance with the objective demands of the apparatus. 
Under technological rationality man internalizes the rationality of the machine. ${ }^{4}$ The categories in which man now thinks are: efficiency, productivity, feasibility, profitability, expediency and convenience. Marcuse explains this in detail: "The facts directing man's thought and action are not those of nature which must be accepted in order to be mastered, or those of society which must be changed because they no longer correspond to human needs and potentialities. Rather they are those of the machine process, which itself appears as the embodiment of rationality and expediency" (Marcuse 1941, 46).

The key insight is that the individual is not deprived of his individuality by some external force as it was for example the organization of capital whose moments would be abolished by the revolution as Marx argued. Instead, the individual is deprived of his autonomy and individuality by the same rationality under which he is living. This is one factor in explaining the diminishment of revolutionary consciousness: "Today, the prevailing type of individual is no longer capable of seizing the fateful moment which constitutes his freedom. He has changed his function; from a unit of resistance and autonomy, he has passed to one of ductility and adjustment. It is this function which associates individuals in masses" (Marcuse 1941, 55).

Marcuse concludes his early thoughts on technology in the same optimistic tone as Heidegger (1977) did. In technology Marcuse sees an opportunity for individual development. This opportunity presents itself namely in the technological capability of reducing necessary time spent at work. ${ }^{5}$ To put it in Marcuse's words: "Technological progress would make it possible to decrease the time and energy spent in the production of the necessities of life, and a gradual reduction of scarcity and abolition of competitive pursuits could permit the self to develop from its natural roots. The less time and energy man has to expend in maintaining his life and that of society, the greater the possibility that he can "individualize" the sphere of his human realization. Beyond the realm of necessity, the essential differences between men could unfold themselves: everyone could think and act by himself, speak his own language, have his own emotions and follow his own passions" (Marcuse 1941, 64).

In the following lines I will examine how Marcuse perceived the emancipatory but also oppressive role of technology.

\section{THE TRANSFORMATIVE POTENTIAL OF TECHNOLOGY}

In Eros and Civilization Marcuse offered his vision of the possibility of non-repressive civilization. This possibility is partly brought about by the technological advancement which helped the abolishment of toil. In order to understand the possibility of civilization without repression and the role of technology in it, a brief overview of Freud's thoughts on civilization is necessary.

\footnotetext{
${ }^{4}$ By using term "technological rationality" Marcuse attempts to describe the effect that advanced industrial civilization has on men. This term elaborates Marx observation which early industrial society had on man: "Machine accommodates itself to the weakness of man in order to make a machine out of the weak man" (Marx 1985, 290). ${ }^{5}$ It should be noted that in Marcuse's theory liberation means liberation from the burden and duration of work. In On the Philosophical Foundations of the concept of Labor in Economics Marcuse (1933) demonstrated that individual passions and development come on the other side of the labor medal - the play which is strictly reserved for leisure time. Thus freedom for Marcuse means minimizing labor time and increasing leisure time. Marcuse saw in technology an opportunity for this.
} 
Freud (1962) understands the development of an individual as the permanent conflict between eros and thanatos. The conflict of these two basics human instincts is similar to the development of civilization through conflict also. Conflict of the civilization takes the form of conflict between the pleasure principle and reality principle. While the pleasure principle seeks to maximize gratification, the reality principle imposes restrictions upon the pleasure principle demanding the negation of instincts and postponing of gratification. Renunciation of instincts is then a pre-requirement for the development of civilization. Freud (1962) enumerates two basic renunciations which are demanded by civilization: renunciation of sexual gratification and renunciation of aggression. According to Freud (1962), civilization became an increasingly male business. Since men do not have unlimited quantities of sexual energy (libido) they have to make a distribution of their libido. In doing so, civilization exploits sexual energy for its further advancement. In order to eliminate aggression among the members of the same group civilization tends to bind members of the community by libidinal ties. Civilization uses its utmost effort to advance the strong identification of the members. Thus, once again sexual energy had to be restricted in order to establish friendship relations. Regarding the further development of civilization Freud offers somehow pessimistic conclusion arguing that with its development civilization would require even more restrictions: “... to represent the sense of guilt as the most important problem in the development of civilization and to show that the price we pay for our advance in civilization is a loss of happiness through the heightening of the sense of guilt" (Freud 1962, 81).

The main problem of Freud's theory of civilization development is that he considered repression to be a universal principle. In other words, Freud's theory is lacking a differentiation of historical epochs. In a word, Freud's theory is ahistorical. Marcuse (1974[1956]) immediately detects this deficiency and argues that the necessity for repression is always historical and that it is caused by the societal production and reproduction conditioned by the scarcity of material goods. In order to differentiate more clearly between basic biological and socially conditioned repression, Marcuse introduces the terms "surplus repression" and "performance principle": "the restrictions necessitated by social domination. This is distinguished from (basic) repression: the 'modifications' of the instincts necessary for the perpetuation of the human race in civilization. Performance principle [is] the prevailing historical form of the reality principle" (Marcuse 1974, 33). As it was mentioned earlier, labor is the central category of Marcuse's critical theory. Marcuse understands freedom in terms of the transformation of the character of labor. And it is precisely the notion of labor that is behind the "surplus repression" and the "performance principle". Repression and restriction of instincts was needed in the historical era of material scarcity which demanded toil in order to provide for the basic needs. But the advancement of modern industrial civilization owes much to the rapid development of technology which in turn changes the amount of energy and time spent at labor. In other words, technology holds negating potential for overcoming the "kingdom of necessity". To put it in Marcuse's words: "The available resources make for a qualitative change in the human needs. Rationalization and mechanization of labor tend to reduce the quantum of instinctual energy channeled into toil (alienated labor), thus freeing energy for the attainment of objectives set by the free play of individual faculties. Technology operates against the repressive utilization of energy in so far as it minimizes the time necessary for the production of the necessities of life, thus saving time for the development of needs beyond the realm of necessity and of necessary waste" (Marcuse 1974, 63). The main 
argument is that technology can liberate eros or in other words that the comprehensive satisfaction of needs can be achieved without toil. This in turn is possible only with the changed characteristic of labor. Marcuse emphasizes this possibility: "This quality would reflect the prevalent satisfaction of the basic human needs (most primitive at the first, vastly extended and refined at the second stage), sexual as well as social: food, housing, clothing, leisure. This satisfaction would be (and this is the important point) without toil - that is, without the rule of alienated labor over the human existence" (Marcuse 1974, 94). In Eros and Civilization Marcuse envisages a welfare society where productivity is not conditioned by an instinctual repression and alienated labor. Owing to the technology and growing mechanization of work a returning of libidinal energy to eros is possible. Technology thus has the potential of eliminating alienated labor. The technology's liberating potential clearly contradicts Freud's conclusion about further development of civilization and on the other hand it complements Freud's theory of individual development by offering a possibility to liberate eros.

The question of technology is also an important part of Marcuse's analysis of soviet marxism. ${ }^{6}$ Marcuse (1958) argued that the technological development of western societies enables parallel sustainability of the military industry and raising living standard. Marcuse (1958) argues that this means that the soviet society actually supports the stability and unity of capitalistic society. The soviet society placed enormous efforts in technological and industrial development. Marcuse (1958) considers an attempt to win the economic and technological race with western society a crucial factor of soviet marxism. According to Marcuse, the soviet society should be partly criticized on a technological basis: "In its most visible form, the link is in the technical economic basis common to both systems, i.e., mechanized (and increasingly mechanized) industry as the mainspring of societal organization in all spheres of life. As against this common technical-economic denominator stands the very different institutional structure-private enterprise here, nationalized enterprise there" (Marcuse 1958, 5-6). Marcuse perceived in the soviet society the same factors which hindered the development of individuality and autonomy in western society. In other words, in his analysis Marcuse applies the previously mentioned concept of "technological rationality" in order to demonstrate the devastating effect of technology on the individual: “... the same mechanization and rationalization generated attitudes of standardized conformity and precise submission to the machine which required adjustment and reaction rather than autonomy and spontaneity. If nationalization and centralization of the industrial apparatus goes hand in hand with (...) the subjugation and enforcement of labor as a fulltime occupation, progress in industrialization is tantamount to progress in domination: attendance to the machine, the scientific work process, becomes totalitarian, affecting all spheres of life" (Marcuse 1958, 84). From this citation it could be noted that the soviet's technological development not only had not liberated individuals, but had subjected them even more to the production apparatus. Marcuse introduces the term "new rationality" for which he considers to be an adequate description of

\footnotetext{
${ }^{6}$ Soviet Marxism: A Critical Analysis is usually omitted from the bibliography of those who are critical as well as of those who are sympathetic to Marcuse's theory. The reason for omitting it is that Soviet Marxism was written during Marcuse's work in the Russian Institute and it was written on the order of the CIA. Marcuse himself did not consider it a part of his main current of thought. Nevertheless, Soviet Marxism is important in Marcuse's theory since in it he develops further the notion of "technological rationality", demonstrates the distortion of Marx's theory which in turn testifies to Marcuse's commitment to Marx. In conclusion, Soviet Marxism is an eastern counterpart of One Dimensional Man.
} 
soviets' reality. ${ }^{7}$ The term "new rationality" is actually an augmented notion of the previously mentioned and demonstrated "technological rationality". It is Marcuse's contention that the soviet's "new rationality" largely uses "technological rationality". What Marcuse attempted to demonstrate is that in its essence soviet society, just like capitalist society, is repressive and that it uses technology in the same repressive way as its capitalistic counterpart. This draws the conclusion that the soviet and capitalist society share the same technical base.

It was previously mentioned that in Eros and Civilization Marcuse considered that technological development per se can initiate social transformation. But now Marcuse learned that technology can produce even more repression regardless of the better standard of living. It is now important to note that Marcuse perceives social transformation solely as a political decision to use technology for different (liberating) purposes: "Modern machinery is susceptible to capitalist as well as socialist utilization. This amounts to saying that mature capitalism and socialism have the same technical base, and that the historical decision as to how this base is to be used is a political decision (...) No matter how high the level of technical progress and material culture, of labor productivity and efficiency, the change from socialist necessity to socialist freedom can only be the result of conscious effort and decision. The maintenance of repressive production relations enables the Soviet state, with the instrumentalities of universal control, to regiment the consciousness of the underlying population" (Marcuse 1958, 185-190).

In One Dimensional Man, Marcuse offers his final critical statement on technology. Thus One Dimensional Man should be read as Marcuse's attempt to create critical theory of technologically advanced societies. While before he emphasized the neutral or even liberating character of technology, Marcuse (1964) is now certain that the domination is immanent to technology: "In the face of the totalitarian features of this society, the traditional notion of the "neutrality" of technology can no longer be maintained. Technology as such cannot be isolated from the use to which it is put; the technological society is a system of domination which operates already in the concept and construction of techniques" (Marcuse 1964, xlvi). Marcuse's main (Hegelian) thesis is that technologically advanced societies produced and enabled the technologization of lordship. In other words, Marcuse noticed the proletariat's integration and with it the disappearance of revolutionary consciousness. This integration was possible on the technological basis. Marcuse observes the changes in the structure and function of the two antagonistic classes and argues: "And to the degree to which technical progress assures the growth and cohesion of the communist society, the very idea of qualitative change recedes before the realistic notions of a non-explosive evolution" (Marcuse 1964, xliii). The technological basis resembles an attempt to mitigate the gap between two antagonistic classes. It is precisely in this resemblance that Marcuse finds the ideological function of technology in suppressing the revolution: "Here, the socalled equalization of class distinctions reveals its ideological function. If the worker and his boss enjoy the same television program and visit the same resort places, if the typist is as attractively made up as the daughter of her employer (...) then this assimilation indicates not the disappearance of classes, but the extent to which the needs and satisfactions that

\footnotetext{
${ }^{7}$ In its usage in the soviet's analysis term "new rationality" has a wider and more comprehensive meaning than the term "new rationality". A detailed examination of the "new rationality" would be out of the paper's scope but it should be noted that according to Marcuse "new rationality" incorporates a set for creating social reality: "technological rationality", pragmatic production of desired attitudes, ideological character of language and ritualization and magic usage of Marx's theory.
} 
serve the preservation of the Establishment are shared by the underlying population" (Marcuse 1964, 10).

Technological advancement also altered the definition of a laborer. In Marx's theory the laborer was understood as a manual laborer who by toil consumes his power. Satisfaction of needs was largely basic and it consisted of nourishment and sleep. Both of them helped the laborer regain his strength in order to perform the same toil tomorrow. Marcuse (1964) noticed that technology overcame this physiological and biological fact of Marx's era: "The technological change which tends to do away with the machine as individual instrument of production, as 'absolute unit', seems to cancel the Marxian notion of the 'organic composition of capital' and with it the theory of the creation of surplus value" (Marcuse 1964, 31). According to Marcuse (1964), the crucial change is that instead of the laborer, it is the machine that creates a surplus value. The transition from classical to advanced capitalism abolished Hegelian and Marxian relation of lordship, serfdom and overcoming. Marcuse describes this change: "The capitalist bosses and owners are losing their identity as responsible agents; they are assuming the function of bureaucrats in a corporate machine. Within the vast hierarchy of executive and managerial boards extending far beyond the individual establishment into the scientific laboratory and research institute, the national government and national purpose, the tangible source of exploitation disappears behind the facade of objective rationality (...) And this mutual dependence is no longer the dialectical relationship between Master and Servant, which has been broken in the struggle for mutual recognition, but rather a vicious circle which encloses both the Master and the Servant" (Marcuse 1964, 35-36). Marcuse believes that the containment of social change is dependable on the level in which the politics of "technological rationality" is able to elevate standard of living by efficient subjection of science and technological inventions. Marcuse sums up: " $\ldots$ the highest stage of capitalist development corresponds, in the advanced capitalist countries, to a low of revolutionary potential" (Marcuse 1972, 5).

Marx argued that the movement of history is influenced by the specific social organization of production, and in that sense it is evident that Marx considered the character of technology to be neutral: "In acquiring new productive forces men change their mode of production; and in changing their mode of production, in changing the way of earning their living, they change all their social relations. The hand-mill gives you society with the feudal lord; the steam-mill society with the industrial capitalist" (Marx 2010[1847], 73). But Marcuse differs here from Marx in perceiving the totalitarian character of technology. According to Marcuse (1964) this totalitarian character of technology is evident in the subjugation of men and nature to the logos of technics. The implications of this are the impossibility of human autonomy and freedom in serving the technical apparatus which raises the conformity and productivity of labor. For Marcuse this implies that human relations will obtain the character of technological functioning. ${ }^{8}$ Or in other words,

\footnotetext{
${ }^{8}$ In effect Marcuse is influenced by Lukács' (1971) understanding of mutual relations between reification and consciousness. Lukács (1971) understood reification as a historical form of thingness in which relations among people obtain character of commodity - human relations become as relations among things. According to Lukács social reality could be penetrated only by piercing through commodity relations. To put it in Lukács' words: "It stamps its imprint upon the whole consciousness of men; his qualities and abilities are no longer an organic part of his personality, they are things which he can 'own' or 'dispose of' like the various objects of external world. And there is no natural form in which human relations could be cast, no way in which man can bring his physical and psychic 'qualities' into play without their being subjected increasingly to this reifying process" (Lukács 1971, 100). As it may be noticed, Marcuse shares Lukács' concept of reification but instead of commodities, Marcuse argues that insight into reified social relations is possible through technology.
} 
technological reification will become the dominant mode of social reality: "Only in the medium of technology, man and nature become fungible objects of organization. The universal effectiveness and productivity of the apparatus under which they are subsumed veil the particular interests that organize the apparatus. In other words, technology has become the great vehicle of reification - reification in its most mature and effective form" (Marcuse 1964, 172).

\section{THE NEW CATEGORICAL IMPERATIVE}

Noticeable in Heidegger's and Marcuse's understanding of technology and its potential is this overwhelming reach of technology. This reach that touched all life (organic as well as inorganic) and changed the way we perceive nature but also the way we perceive life in general. Jonas captures this profound change due (or thanks) to technology: "The good or bad (...) was near the action (...) and it wasn't a thing of far planning (...) The effect of action was small, time frame for prognosis, for setting aims and for calculating was short, the control of circumstances was limited (...) far reaching consequences were left to destiny, coincidences or to prophecies" (Jonas 1990, 18). This was, of course, before the introduction of modern technology. With modern technology human behavior also changed. Technology transformed the character of labor, the future could be calculated, life could even be prolonged, the human battle with Nature finally ended. Humanity was victorious. Or was it indeed? Technological reason translated ideas of speculative reason into the reality of technological reason. But to what effect? The atomic bomb represents the peak of technological reason. It also represents how far technology can reach into life and the future. For Jonas (1990) what is at stake are the idea of life and the complete planet's biosphere. Thus, Jonas formulates a new ethical imperative for technological civilization: "The Idea of humanity must exist (...) Act so that the effects of your action are in accordance with the permanence of human life on Earth (...) Act so that the effects of your actions are not detrimental for the future possibility of life (...) Do not put in jeopardy the conditions for unlimited existence of humanity on Earth" (Jonas 1990, 28). Unlike Marcuse who unconditionally placed trust in the capabilities of an average person for social change, Jonas was pretty much disillusioned with the idea that the change could come from down below - from the people. Thus, Jonas (1990) delegated the implementation of this new categorical imperative to the person of statesman. Jonas (1990) even went so far to call for the "dictatorship of the enlightened". The reason for this is that Jonas witnessed the devastating effect of atomic bomb dropped on Hiroshima. Jonas (like Heidegger and Marcuse) called for a new mode of instrumental usage of technology - a mode that would not be harmful to life in all its forms and to the planet itself. Although Jonas (1990) saw this goal attainable through the "dictatorship of enlightened" his idea of nondestructive usage of technology fits precisely into the notion of "technoaesthetics": a harmonious and artistic usage of technology for creating and preserving beauty. And life itself is one form of beauty. 


\section{TECHNOAESTHETICS AND LIBERATION}

What can one conclude from the previous chapters on Heidegger, Marcuse and Jonas? These philosophers saw great power and promise in technology, but they also saw a peril - peril for humanity and Nature. For Heidegger the escape from this peril was through thinking as a distinct human capability. Thinking in this sense would mean contemplating on how to use technology in accordance with Nature, in the creation of a more humane world. This usage of technology implies in itself the category of beauty. Since all things in Nature are already ordered in a harmonious and aesthetical way, it is only technology that can either foster this aesthetical harmony or disturb it. For Heidegger this synergy of technology and aesthetics was mediated through thinking as contemplating. Marcuse was probably most enthusiastic regarding the liberating potential of technology. He saw in it a tremendous potential for the liberation of individuals from toil and for the creation of an aesthetic society with the help of technology. Marcuse thought that this liberating potential would come after the (radical) change in individuals' consciousness. For him technology imbued with art would act in a harmonious way with Nature. Jonas urged that in technological civilization a new ethics is required. Ethics that would guide the usage of technology in a way that is not disastrous only to present life, but to the very idea of life. And if we accept that life is a form of beauty, perhaps its highest form, then in order to change the direction of the application of technology, technology itself must be supplemented with the category of beauty.

I propose to introduce the term "technoaesthetics" since I consider it to be coincidental within the framework of Marcuse's theory as well as with Heidegger's and Jonas' thoughts on technology. Notion "technoaestehtics" relates first to the invention and creation of aestheticized technology imbued with beauty. And second, aesthetics would attain technological instrumentality, it would become techne in the comprehensive Greek meaning of the word. Simondon in his letter to Derrida ${ }^{9}$ explains this convergence of technology and aesthetics: "The Garabit viaduct, on the Truyère, is perhaps even more remarkable, due to the inversed catenary curve of its main arc and how it's embedded in the rocks of its bases. It's beautiful also because it's in the middle of nature. The viaduct traverses nature and is traversed by it. Finally, and perhaps even more so perhaps, it's beautiful due to the conditions of its construction: first the two parallel half-bridges set up against the two hills; had there been wind on the day they were joined, it could have been catastrophic. 'But there will be no wind,' Eiffel said. And indeed, there was no wind. The two half-bridges turned slowly and simultaneously under the traction of the cables, at a 90degree angle. They ended up settling, at their outer ends, against each other, and were bolted. And since then the viaduct has existed as a unity, as something that's completely perfect. This is an example of a techno-aesthetic work: perfectly functional, successful, and beautiful. It's technical and aesthetic at the same time: aesthetic because it's technical, and technical because it's aesthetic. There is intercategorial fusion" (Simondon 2012, 2).

\footnotetext{
9 “'On Techno-Aesthetics' is a letter by Gilbert Simondon to Jacques Derrida about the foundation of the Collège International de Philosophie (CIPH). It is dated July 3rd, 1982, and it is handwritten on letterhead paper from the Université René Descartes. The letter was published in Issue 12 of Papiers, a collection directed by CIPH's program directors. The issue also features a typewritten text by Simondon on educational reform, which is not included here. The letter begins with a one-paragraph introduction in which Simondon addresses Derrida ('Cher Camarade') and states his support for the foundation of CIPH. The following translation starts with the second paragraph of the letter, where Simondon launches into a reflection on techno-aesthetics" - Translator's introduction.
} 
In the last instance Marcuse sought possible the synergy of technology and art in the creation of a beautiful humane society. For this synergy to happen, technology ought to be imbued with the main aesthetical principle -beauty. Simondon also argued that the technoaesthetical convergence could be extended "through the contemplation and handling of tools" (Simondon 2012, 2). Nondestructive to life, aesthetical, the creation of technology is perhaps best given in the micro example of a hand wrench: "What's remarkable about this tool is that the two heads allow for an easy grip. One holds the head that's not being used in one's closed fist. If the tool were merely a straight piece of metal, it would hurt to hold it. The head that's not being used is like a compact and resistant handle. As a whole, it's a very nice object weighing approximately one hundred grams. It's a tool that answers very well to what it is required to do. Made in bronze, it gives aesthetic pleasure when one contemplates it" (Simondon 2012, 3). In what "tecnoaesthetics" reveals itself is not in contemplation (like Heidegger assumed), but in mediation, usage and application, in a sense that offers a joy and in usage that does not destruct but reveals what is hidden in a usage that liberates (compare with Heidegger's understanding of the essence of technology). Sismondi once again offers an example: “... contemplation is not techno-aesthetics' primary category. It's in usage, in action, that it becomes something orgasmic, a tactile means and motor of stimulation. When a nut that is stuck becomes unstuck, one experiences a motoric pleasure, a certain instrumentalized joy, a communication--mediated by the tool-with the thing on which the tool is working (...) Art is not only the object of contemplation; for those who practice it, it's a form of action that is a little like practicing sports. Painters feel the stickiness of the paint they are mixing on the palette or spreading on the canvas" (Simondon 2012, 3). For Simondon (2012) there is a continuous spectrum that unites technology with aesthetics.

Perhaps the best understanding of the notion of "technoaesthetics" could be offered by following Marcuse's arguments on art and technology. Marcuse carried out the most detailed theoretical analysis on this convergence of arts and aesthetics. Thus, not only could Marcuse's arguments be used to derive the notion of "technoaethetics" but the term also best captures Marcuse's vision of an aesthetic society made possible by qualitatively different usage and application of technology.

The crucial insight that Marcuse draws from thematization of technology is the conclusion on the further development of "historical project" towards "greater historical truth" and the inherent possibility of unison between men and nature. This relationship of harmony with nature is possible on the technological grounds and Marcuse describes it with the term "pacification of existence": "Pacification of existence means the development of man's struggle with man and with nature, under conditions where the competing needs, desires, and aspirations are no longer organized by vested interests in domination and scarcity - an organization which perpetuates the destructive forms of this struggle" (Marcuse 1964, 18). Pacification of existence towards which Marcuse points is not only concentrated to the abolishment of alienated labor but also to the reorganization of the technological basis of society. Both abolishment of alienated labor and reorganization of the technological basis are requirements for qualitative change. Marcuse describes this qualitative change: "The technological transformation is at the same time political transformation, but the political change would turn into qualitative social change only to the degree to which it would alter the direction of technical progress - that is, develop a new technology. For the established technology has become an instrument of destructive politics. Such qualitative change would be transition to a higher stage of civilization if technics were designed and utilized for the 
pacification of the struggle for existence" (Marcuse 1964, 232). Marcuse understands this qualitative change as a methodical political action in which technology is liberated from its instrumental use and deployed towards the creation of a more humane society. The pacification of existence is thus possible by the completion of a technological project: "If the completion of the technological project involves a break with the prevailing technological rationality, the break in turn depends on the continued existence of the technical base itself. For it is this base which has rendered possible the satisfaction of needs and the reduction of toil - it remains the very base of all forms of human freedom. The qualitative change rather lies in the reconstruction of this base - that is, in its development with a view of different ends" (Marcuse 1964, 236). The technological achievement renders possible the calculation of what it means to live a better life: "For example, what is calculable is the minimum of labor with which, and the extent to which, the vital needs of all members of a society could be satisfied (...) calculable is the degree to which, under the same conditions, care could be provided for the ill, the infirm, and the aged" (Marcuse 1964, 236-237). The pacification of existence thus presupposes the qualitative change in usage of technology. It negates both the destructive efficiency and performance principle. As a regulating idea in using technology, pacification of existence tends to exploit the liberating potential of technology. This qualitative turn it its usage Marcuse describes: "To the degree to which the goal of pacification determines the Logos of technics, it alters the relation between technology and its primary object, Nature. Pacification presupposes mastery of Nature, which is and remains the object opposed to the developing subject. But there are two kinds of mastery: a repressive and a liberating one (...) In the process of civilization, Nature ceases to be mere Nature to the degree to which the struggle of blind forces is comprehended and mastered in the light of freedom" (Marcuse 1964, 240-241).

The reality of reason on which Marcuse insists throughout his works is possible by transcending technological rationality to a post-technological rationality where the principle of beauty fuses with the principle of social organization. What Marcuse proposes is the cooperation of art and technics towards the creation of aestheticized society. This cooperation is possible based on the fact that both technology and art hold the vision of a better and more beautiful world with a difference in the arts' incapability to translate these ideas into the creation of society. Marcuse describes this cooperation of art and technology: "Technique, assuming the features of art, would translate subjective sensibility into objective form, into reality" (Marcuse 1969, 24).

The cooperation between art and technology and pacification of existence are two determinants of the new society, namely the aesthetic ethos. The aesthetic ethos places the principle of beauty as a new organizing principle of society. The aesthetic as a new form of society is possible on the basis of scientific and technological development. ${ }^{10}$ On the basis of a given civilizational development, aesthetics can change its historical topos. Society can become the subject of aesthetics and that in turn would affect the affirmative character of culture. The cooperation of art and technic would change them both. Art would define the construction and the form of machines, while at the same time art would receive some technical denotations. Their product would be society as a work of art and beauty an important characteristic of human's freedom. This is implicated in the term "technoaesthetics". Here is

\footnotetext{
${ }^{10}$ Compare with Marcuse's (1937b) early essay The Affirmative Character of Culture where he argued that beauty pertains to art only and that this idealized more beautiful world could never be turned into practice.
} 
Marcuse's final statement and his vision of artistic society: "In the reconstruction of society for the attainment of this goal, reality altogether would assume a Form expressive of the new goal. The essentially aesthetic quality of this Form would make it a work of art, but inasmuch as the Form is to emerge in the social process of production, art would have changed its traditional locus and function in society: it would have become a productive force in the material as well as cultural transformation. And as such a force, art would be an integral factor in shaping the quality and the 'appearance' of things, in shaping reality, the way of life. This would mean the Aufhebung of art: the end of the segregation of the aesthetic from the real, but also the end of the commercial unification of business and beauty, exploitation and pleasure. Art would recapture some of its more primitive 'technical' connotations: as the art of preparing (cooking!), cultivating, growing things, giving them a form which neither violates neither their matter nor the sensitivity..." (Marcuse 1969, 31-32).

\section{CONCLUSION}

I have attempted to demonstrate the convergence of aesthetics (mainly its category of beauty) and technology. This convergence was expressed through the notion of "technoaetshetics". The notion was derived through a critical examination of Heidegger's Jonas', Marcuse's and later Simondon's texts on technology (and aesthetics). For Heidegger, technology should not be understood in terms of instrumental usage or application, but as a mode of revealing, enframing and setting-forth. Modern technology profoundly changed human understanding of Nature. But this change is not necessarily to the benefit of humanity. Heidegger argued that the greatest danger for humanity is probably hidden in the very essence of technology. Thus, Heidegger considered that between humans and technology, a thinking as a distinct human capability should mediate. Thinking understood as contemplating the usage of technology in accordance with the preservation of Nature. Jonas witnessed the unencumbered potential of technology released at the same time when the a-bomb dropped on Hiroshima. For Jonas this event signified the peak of destructive mode of usage of technology as well as the (negative) peak of technological reason. Thus, Jonas reformulated Kant's well-known categorical imperative stating that life must exist and that contemporaries are responsible to the possibility of realization of the idea of life. This is only possible with the change of our usage of technology, a shift from the destructive to nondestructive or even creative application of technology. This qualitative and sensitive change in the character of technology could only occur if technology itself is imbued with the ideas of a better life - ideas that were safeguarded in the dimension of aesthetics. Marcuse was perhaps one of the first political and social theorists to perceive technology as a new protagonist of the historical process. Marcuse argued that technology and art can change their functions and converge. Common to both technology and art are ideas and promises of a better more beautiful life and world. This ideal, expressed through the notion of "technoaesthetics", could be attained through sensitive cooperation between art and technology. Art would not be any more beautiful in appearance and technology would be delivered from its destructive use. In the cooperation of technology and art, as Marcuse thought it, could bring a qualitative change - the creation of aesthetic ethos. 
"Technoaesthetics" encompasses not only change in the instrumental usage of technology but the change in the very essence of technology. The decision for this change is a political one and perhaps should come from above as Jonas argued.

Acknowledgement. This paper under the title The Political Role of Technology has been previously published in Serbian Political Thought 15, 1 (2017). Parts of this paper were also published in author's book Kritika i otpor: osnovne crte kritičke filozofije Herberta Marcusea, Zagreb: Naklada Breza. The current paper contains some revised ideas and further elaborates the notion of "technoaesthetics". For this I am especially grateful to the anonymous reviewers.

\section{REFERENCES}

Farr, Arnold L. Critical Theory and Democratic Vision: Herbert Marcuse and Recent Liberation Philosophies. New York: Lexington Books, 2009.

Freud, Sigmund. Civilization and Its Discontents, New York: W W Norton \& Company Inc., 1962.

Habermas, Jürgen. "Zum Geleit". In Antworten auf Herbert Marcuse, ed. Jürgen Habermas. Frankfurt: Suhrkamp, 1968.

Heidegger, Martin. The Question Concerning Technology, 1977. Downloaded from: http://www.psyp.org/ question_concerning_technology.pdf (March, $7^{\text {th }}$ 2017).

Jonas, Hans. Princip odgovornosti: pokušaj jedne etike za tehnološku civilizaciju. Sarajevo: Veselin Masleša, 1990.

Lukács, Georg. History and Class Consciousness: Studies in Marxist Dialectics. Great Britain: The Merlin Press Ltd., 1971.

MacIntyre, Alasdair. Marcuse. Great Britain: Fontana, 1970.

Marcuse, Herbert. "On the Concrete Philosophy”. In Heideggerian Marxism, eds. John Abromeit, and Richard Wolin. Lincoln and London: University of Nebraska Press, 1929.

Marcuse, Herbert. "On the Philosophical Foundations of the Concept of Labor in Economics". In Heideggerian Marxism, eds. John Abromeit, and Richard Wolin. Lincoln and London: University of Nebraska Press, 1933.

Marcuse, Herbert. "Industrialization and Capitalism in the Work of Max Weber". In Negations: Essays in Critical Theory, eds. Jeremy Shapiro et.al. London: MayFlyBooks, 1937.

Marcuse, Herbert. "The Affirmative Character of Culture". In Negations: Essays in Critical Theory, eds. Jeremy Shapiro et.al. London: MayFlyBooks, 1937b.

Marcuse, Herbert. “Some Implications of Modern Technology”. In Technology, War and Fascism; Collected Papers of Herbert Marcuse, volume I, eds. Herbert Marcuse, Douglas Kellner. London and New York: Routledge, 1941.

Marcuse, Herbert. Soviet Marxism: A Critical Analysis. New York: Columbia University Press, 1958.

Marcuse, Herbert. One-Dimensional Man: Studies in the Ideology of Advanced Industrial Society. London and New York: Routledge, 1964.

Marcuse, Herbert. An Essay on Liberation. Boston: Boston Beacon Press, 1969.

Marcuse, Herbert. Counterrevolution and Revolt. Boston: Beacon Press, 1972.

Marcuse, Herbert. Eros and Civilization: Philosophical Inquiry into Freud. Boston: Beacon Press, 1974.

Marcuse, Herbert. Hegel's Ontology and the Theory of Historicity. London: MIT Press, 1987.

Marx, Karl and Friedrich Engels. Rani radovi, $7^{\text {th }}$ edition. Zagreb: Naprijed, 1985.

Marx, Karl. The Poverty of Philosophy: Answer to the Philosophy of Poverty by M. Proudhon, 2010.

Schoolman, Morton. The Imaginary Witness: The Critical Theory of Herbert Marcuse. USA: New York University Press, 1984.

Simondon, Gilbert. "On Techno-Aesthetics”. Parrhesia 14 (2012): 1-8.

Whitfield, J. Stephen. "Refusing Marcuse. Fifty Years After One-dimensional Man”. Dissent 61, 4 (2014): 102107. 


\section{TEHNOESTETIKA: \\ NEKA ZAPAŽANJA O KONVERGENCIJI ESTETIKE I TEHNOLOGIJE}

U radu autor analizira pitanje i upotrebu tehnologije. Autor se poziva na rad Hajdegera, Markuzea i Jonasa. Naglasak je na radu Markuzea jer je on na najbolji način razvio teoriju oslobađanja kroz tehnologiju i ponudio detaljnu viziju estetike etosa. Autor prvo predstavlja Hajdegerovo poimanje tehnologije na koje je u velikoj meri uticao rad Markuzea. Zatim, autor razmatra Jonasovu premisu za novu etiku tehnološke civilizacije. Na kraju, pozivajući se na Hajdegera, Markuzea, Jonasa i Simondona, autor predstavlja termin "tehnoestetika" kao pojam koji opisuje i obuhvata kvalitativno različite ideje o upotrebi i primeni tehnologije.

Ključne reči: umetnost, tehnologija, tehnika, oslobođenje, Hajdeger, Markuze, Jonas, tehnološka racionalnost, tehnoestetika. 